\title{
CROSS-CULTURAL DIFFERENCES IN DRIVER RISK-PERCEPTION
}

\author{
MiCHAEl SivaK \\ The University of Michigan, Transportation Research Institute, Ann Arbor, MI 48109-2150, \\ U.S.A. \\ JOSÉ SOLER \\ The University of Valencia, Faculty of Psychology, Valencia, Spain
}

ULRICH TRÄNKLE

The University of Münster, Institute of Psychology, Münster, Federal Republic of Germany

Jane Maria Spagnhol

The Federal University of Uberlandia, Department of Psychology, Uberlandia, Brazil

(Received 13 May 1988)

\begin{abstract}
This study investigated differences in risk-perception among U.S., Spanish, West German, and Brazilian drivers. Subjects estimated the risk involved in slide-projected traffic scenes. The scenes, photographed in the United States and Spain, were rated for the amount of risk by using a seven-point scale. The subject groups in each country included younger, middleaged, and older nonprofessional drivers, as well as middle-aged professional (bus, taxi, or truck) drivers. In the data analyses, the independent variables were subjects' country, age, professional driving experience, and sex, and 23 dichotomously coded characteristics of the traffic scenes. The following are the main findings: (1) Spanish drivers reported the highest risk, while U.S. drivers reported the lowest risk; (2) younger drivers tended to report lower risk than middleaged and older drivers; (3) nineteen of the 23 analysed characteristics of traffic scenes contributed significantly to risk ratings, even after simultaneously controlling for the effects of all other scene characteristics; (4) ten scene characteristics had a differential effect on the risk ratings in the four tested countries; (5) two scene characteristics had a differential effect on the risk ratings in the four tested subject groups; (6) none of the variables affected differentially the risk ratings of professional vs. nonprofessional drivers and males vs. females. These findings provide information concerning the desirable country- and age-specific emphasis in driver education, driver licensing, and public information campaigns.
\end{abstract}

\section{INTRODUCTION}

This study is one of three studies performed as part of research on cross-cultural differences in driver risk-behavior. The other two studies investigated simulated driver risktaking (Sivak, Soler, and Tränkle 1989a) and driver self-assessment (Sivak, Soler, and Tränkle 1989b).

The present study investigated perception of risk in slide-projected traffic scenes in the United States, Spain, West Germany, and Brazil. The primary objective was to identify characteristics of traffic scenes that might contribute differentially to risk-perception in the studied countries. The secondary objective was to study age- and sexrelated differences in driver risk-perception.

Driver risk-perception, a factor with potential influence on traffic safety, has been investigated in studies performed in several countries, including the United States (Finn and Bragg 1986), Canada (Matthews and Moran 1986), West Germany (von Benda and Hoyos 1983), and Australia (Cairney 1982). However, the present study is, apparently, the first published experimental investigation of cross-cultural differences in driver riskperception.

\section{METHOD}

\section{Stimuli}

One hundred color slides of traffic scenes were used. Fifty were taken in the United States from the driver's viewpoint. Fifty were taken in Spain, and most of them were 
overviews of traffic scenes and were taken from sidewalks, bridges, etc. These slides were selected from a larger set of approximately 500 slides to provide a broad range of traffic situations. An attempt was made to avoid scenes containing traffic signs unique to one of the two countries. Copies of the same slides were used in all four countries.

Each scene was coded on 23 dichotomous characteristics (Table 1). (For the U.S. scenes only, subjects were given explicit information about one of these characteristicsspeed [see Procedure]. For the Spanish scenes, the coding of speed for the statistical analysis was based on presumed traffic speed given the depicted situation.) The intercorrelations among these 23 variables were generally low. The distribution of these correlations is shown in 'lable 2. (The coding was performed for only 98 scenes, since the coding characteristics were inappropriate for two scenes involving alcohol and sleep.)

\section{Subjects}

Eighty subjects were tested in each country, for a total of 320 subjects. In each country there were 20 subjects ( 10 males and 10 females) in each of the following four groups: 18-21 year olds, 35-45 year olds, 65-75 year olds, and 35- to 45-year-old professional (bus, taxi, or truck) drivers. The distributions of ages of subjects in each group are summarized in Table 3.

The U.S. subjects, who were paid for their participation, came primarily from Ann Arbor, Michigan, a city with a population of approximately 120,000. The Spanish subjects, who participated without reimbursement, came primarily from Valencia, a city with a population of approximately 800,000 . The German subjects came primarily from Münster, a city with a population of about 270,000. The German female middle-aged subjects (professional and nonprofessional drivers) and all older subjects were paid for their participation. The Brazilian subjects, who participated without reimbursement, came primarily from Uberlandia, a city with a population of approximately 420,000 .

\section{Procedure}

Each slide was presented for about 20 seconds. The subjects were asked to evaluate the risk involved in the scenes by using a seven-point scale. The scale had two anchor

Table 1. Characteristics coded for each individual scene

\begin{tabular}{|c|c|c|}
\hline \multirow{2}{*}{ Variable } & \multicolumn{2}{|c|}{ Binary Code } \\
\hline & 0 & 1 \\
\hline $\begin{array}{l}\text { Ambient illumination } \\
\text { Preview distance } \\
\text { Bollowing distance } \\
\text { Lane intrusion } \\
\text { Horizontal alignment } \\
\text { Vertical alignment } \\
\text { Environment } \\
\text { Limited access roadway } \\
\text { Weather } \\
\text { Stopped vehicle in the lane } \\
\text { Traffic density } \\
\text { Road delineation } \\
\text { Animals } \\
\text { Pedestrians or bicyclists } \\
\text { Speed } \\
\text { Road surface friction } \\
\text { Bridge or tunnel } \\
\text { Country of the scene } \\
\text { Complexity } \\
\text { Overtaking } \\
\text { Intersection } \\
\text { Qulck action } \\
\text { Uncertainty }\end{array}$ & $\begin{array}{l}\text { Day } \\
\text { Sufficient } \\
\text { Sufficient } \\
\text { No } \\
\text { Straight } \\
\text { Level } \\
\text { Rural } \\
\text { Yes } \\
\text { Good } \\
\text { No } \\
\text { Low } \\
\text { Good } \\
\text { Absent } \\
\text { Absent } \\
\text { Under } 90 \mathrm{~km} / \mathrm{hr} \\
\text { High } \\
\text { No } \\
\text { U.S.A. } \\
\text { Low } \\
\text { No } \\
\text { No } \\
\text { No need } \\
\text { Low }\end{array}$ & $\begin{array}{l}\text { Night } \\
\text { Insufficient } \\
\text { Insufficient } \\
\text { Yes } \\
\text { Curved } \\
\text { Not level } \\
\text { Urban } \\
\text { No } \\
\text { Poor } \\
\text { Yes } \\
\text { High } \\
\text { Poor } \\
\text { Present } \\
\text { Present } \\
\text { 90 km/hr or over } \\
\text { Low } \\
\text { Yes } \\
\text { Spain } \\
\text { High } \\
\text { Yes } \\
\text { Yes } \\
\text { Potential need } \\
\text { High }\end{array}$ \\
\hline
\end{tabular}


Table 2. Distribution of the absolute values of the intercorrelations among the 23 scene characteristics

\begin{tabular}{c|c|c}
\hline \multicolumn{2}{c|}{ Range } & \multirow{2}{*}{ Frequency } \\
\hline Minimum & Maximum & \\
\hline .000 & .099 & 104 \\
.100 & .199 & 96 \\
.200 & .299 & 29 \\
.300 & .399 & 13 \\
.400 & .499 & 6 \\
.500 & .599 & 5 \\
\hline
\end{tabular}

Table 3. Age distributions of subjects

\begin{tabular}{|c|c|c|c|c|c|c|}
\hline Group & Country & Sex & $\mathbf{N}$ & $\begin{array}{l}\text { Min } \\
\text { Age }\end{array}$ & $\begin{array}{l}\text { Max } \\
\text { Age }\end{array}$ & $\begin{array}{r}\text { Mean } \\
\text { Age }\end{array}$ \\
\hline \multirow[t]{4}{*}{ Younger } & U.S.A. & $\begin{array}{l}\text { Males } \\
\text { Females }\end{array}$ & $\begin{array}{l}10 \\
10\end{array}$ & $\begin{array}{l}18 \\
18\end{array}$ & $\begin{array}{l}21 \\
21\end{array}$ & $\begin{array}{l}19.9 \\
19.0\end{array}$ \\
\hline & Spain & $\begin{array}{l}\text { Males } \\
\text { Females }\end{array}$ & $\begin{array}{l}10 \\
10\end{array}$ & $\begin{array}{l}19 \\
19\end{array}$ & $\begin{array}{l}21 \\
21\end{array}$ & $\begin{array}{l}19.9 \\
20.4\end{array}$ \\
\hline & West Germany & $\begin{array}{l}\text { Males } \\
\text { Females }\end{array}$ & $\begin{array}{l}10 \\
10\end{array}$ & $\begin{array}{l}18 \\
19\end{array}$ & $\begin{array}{l}21 \\
21\end{array}$ & $\begin{array}{l}19.9 \\
19.9\end{array}$ \\
\hline & Brazil & $\begin{array}{l}\text { Males } \\
\text { Females }\end{array}$ & $\begin{array}{l}10 \\
10\end{array}$ & $\begin{array}{l}18 \\
18\end{array}$ & $\begin{array}{l}21 \\
21\end{array}$ & $\begin{array}{l}19.4 \\
19.8\end{array}$ \\
\hline \multirow[t]{4}{*}{ Middle-Aged } & U.S.A. & $\begin{array}{l}\text { Males } \\
\text { Females }\end{array}$ & $\begin{array}{l}10 \\
10\end{array}$ & $\begin{array}{l}35 \\
35\end{array}$ & $\begin{array}{l}45 \\
44\end{array}$ & $\begin{array}{l}40.0 \\
38.9\end{array}$ \\
\hline & Spain & $\begin{array}{l}\text { Males } \\
\text { Females }\end{array}$ & $\begin{array}{l}10 \\
10\end{array}$ & $\begin{array}{l}35 \\
35\end{array}$ & $\begin{array}{l}45 \\
45\end{array}$ & $\begin{array}{l}39.5 \\
40.4\end{array}$ \\
\hline & West Germany & $\begin{array}{l}\text { Males } \\
\text { Females }\end{array}$ & $\begin{array}{l}10 \\
10\end{array}$ & $\begin{array}{l}35 \\
35\end{array}$ & $\begin{array}{l}43 \\
45\end{array}$ & $\begin{array}{l}38.7 \\
40.2\end{array}$ \\
\hline & Brazil & $\begin{array}{l}\text { Males } \\
\text { Females }\end{array}$ & $\begin{array}{l}10 \\
10\end{array}$ & $\begin{array}{l}36 \\
36\end{array}$ & $\begin{array}{l}43 \\
45\end{array}$ & $\begin{array}{l}39.3 \\
40.0\end{array}$ \\
\hline \multirow[t]{4}{*}{ Older } & U.S.A. & $\begin{array}{l}\text { Males } \\
\text { Females }\end{array}$ & $\begin{array}{l}10 \\
10\end{array}$ & $\begin{array}{l}66 \\
68\end{array}$ & $\begin{array}{l}75 \\
75\end{array}$ & $\begin{array}{l}70.6 \\
71.5\end{array}$ \\
\hline & Spain & $\begin{array}{l}\text { Males } \\
\text { Females }\end{array}$ & $\begin{array}{l}10 \\
10\end{array}$ & $\begin{array}{l}66 \\
65\end{array}$ & $\begin{array}{l}75 \\
75\end{array}$ & $\begin{array}{l}70.1 \\
68.7\end{array}$ \\
\hline & West Germany & $\begin{array}{l}\text { Males } \\
\text { Females }\end{array}$ & $\begin{array}{l}10 \\
10\end{array}$ & $\begin{array}{l}65 \\
65\end{array}$ & $\begin{array}{l}75 \\
74\end{array}$ & $\begin{array}{l}68.9 \\
68.1\end{array}$ \\
\hline & Brazil & $\begin{array}{l}\text { Males } \\
\text { Females }\end{array}$ & $\begin{array}{l}10 \\
10\end{array}$ & $\begin{array}{l}65 \\
65\end{array}$ & $\begin{array}{l}67 \\
66\end{array}$ & $\begin{array}{l}65.4 \\
65.2\end{array}$ \\
\hline \multirow[t]{4}{*}{ Middle-Aged Professional } & U.S.A. & $\begin{array}{l}\text { Males } \\
\text { Bemales }\end{array}$ & $\begin{array}{l}10 \\
10\end{array}$ & $\begin{array}{l}35 \\
35\end{array}$ & $\begin{array}{l}45 \\
45\end{array}$ & $\begin{array}{l}38.6 \\
38.1\end{array}$ \\
\hline & Spain & $\begin{array}{l}\text { Males } \\
\text { Females }\end{array}$ & $\begin{array}{l}10 \\
10\end{array}$ & $\begin{array}{l}35 \\
35\end{array}$ & $\begin{array}{l}45 \\
45\end{array}$ & $\begin{array}{l}39.5 \\
39.7\end{array}$ \\
\hline & West Germany & $\begin{array}{l}\text { Males } \\
\text { Females }\end{array}$ & $\begin{array}{l}10 \\
10\end{array}$ & $\begin{array}{l}35 \\
35\end{array}$ & $\begin{array}{l}43 \\
45\end{array}$ & $\begin{array}{l}38.0 \\
38.1\end{array}$ \\
\hline & Brazil & $\begin{array}{l}\text { Males } \\
\text { Females }\end{array}$ & $\begin{array}{l}10 \\
10\end{array}$ & $\begin{array}{l}35 \\
35\end{array}$ & $\begin{array}{l}45 \\
45\end{array}$ & $\begin{array}{l}40.6 \\
39.7\end{array}$ \\
\hline
\end{tabular}


points $(1=$ minimum risk, $7=$ high likelihood of an accident $)$. The remaining points (2 through 6) were unlabelled.

For the U.S. scenes (which were taken from the driver's view point), the subjects were given information about their speed $(25,40$, or $55 \mathrm{mph}[40,65$, or $90 \mathrm{~km} / \mathrm{h}])$. Thus, if the speed was given as $55 \mathrm{mph}[90 \mathrm{~km} / \mathrm{h}]$, they were asked to assume that they were driving at $55 \mathrm{mph}[90 \mathrm{~km} / \mathrm{h}]$, and that the traffic situation ahead was as shown in the scene. For the Spanish scenes (which generally were not taken from the driver's viewpoint but were overviews of a situation), no speed information was given.

The slides were shown always in the same order, with the 50 U.S. slides first, followed by the 50 Spanish slides. No practice slides were given.

The wording of the subject's instructions was constructed in English, and then translated into Spanish, German, and Portuguese.

\section{Statistical analysis}

The primary question of interest in this study was as follows: Do some of the scene characteristics affect the risk ratings of drivers from one country more so than the risk ratings of drivers from another country? To provide information concerning this question, as well as concerning age- and sex-related differences, the main inferential analysis was performed in two steps. In the first step, 320 individual regressions were performed, one for each subject. The predictor variables in these analyses were the 23 scene characteristics in Table 1. The dependent variable was the risk rating for each scene.

In the second step, the beta weights for the 23 scene characteristics (obtained from the regression analyses in the first step) were entered as dependent variables into 23 individual analyses of variance. The independent variables in these analyses were country, subject group, sex, and their interactions.

Of interest in respect to each of the 23 sets of beta weights were the following 19 tests: main effects of country, subject group, sex, and their interactions ( 7 tests), differences from zero of the beta weights for each of the four countries, four subject groups, and two sexes (10 tests), the difference from zero of the grand mean of the beta weights ( 1 test $)$, and the difference between the beta weights of the middle-aged and middleaged professional subjects $(1$ test $)$. Since a total of $437(19 \times 23)$ tests were of interest, the Bonferonni correction (Morrison 1976) was used to set the $p$ for each individual test at a conservative level of .0001144 (.05 divided by 437 ).

\section{RESULTS}

Table 4 shows the mean ratings across all 100 scenes by country, subject group, and sex. Table 5 lists the distributions by country of the rank order for the means of all 100 scenes. The results of a $\chi^{2}$ test indicate that these distributions are not the same, $\left(\chi^{2}(9)=132.2, p<.0001\right)$.

The results of the analyses of the beta weights for the 23 scene characteristics are summarized in Tables 6 and 7. Table 6 shows the mean beta weights for the 23 scene variables, and the results of tests to evaluate whether the beta weights for the individual countries, subject groups, and sexes are statistically different from zero. Table 7 lists those scene variables for which there were significant differences among countries or subject groups.

There were no significant differences between the two sexes for any of the 23 sets of beta weights, and there were no significant interactions among country, subject group, and sex. Finally, there were no significant differences between the two middle-aged groups of subjects (professional vs. nonprofessional) for any of the 23 sets of beta weights.

\section{DISCUSSION}

\section{Effects of scene characteristics}

Nineteen of the 23 analysed characteristics of the traffic scenes contributed significantly to the risk-ratings of the total set of subjects, even after simultaneously controlling 
Table 4. Mean ratings for all 100 scenes by country, subject group, and sex $(1=$ minimum risk, $7=$ high likelihood of an accident)

\begin{tabular}{|c|c|c|}
\hline Variable & Level & Mean rating \\
\hline Country & $\begin{array}{l}\text { U.S.A. } \\
\text { Spain } \\
\text { West Germany } \\
\text { Brazil }\end{array}$ & $\begin{array}{l}4.1 \\
4.8 \\
4.4 \\
4.5\end{array}$ \\
\hline Subject group & $\begin{array}{l}\text { Younger } \\
\text { Middle-aged } \\
\text { Older } \\
\text { Middle-aged professional }\end{array}$ & $\begin{array}{l}4.1 \\
4.5 \\
4.7 \\
4.6\end{array}$ \\
\hline Sex & $\begin{array}{l}\text { Males } \\
\text { Females }\end{array}$ & $\begin{array}{l}4.5 \\
4.4\end{array}$ \\
\hline
\end{tabular}

for the effects of all other scene characteristics. This finding suggests that subjects were sensitive to the majority of the analysed scene characteristics. However, the relative sensitivity for these 19 variables differed by a factor of 5.7. Specifically, the corresponding beta weight for uncertainty was 5.7 times greater than the beta weight for horizontal alignment of the roadway. However, it is not clear whether this differential sensitivity reflects the differential objective contributions to risk of various studied scene characteristics.

The effects of 15 of the 19 significant scene characteristics were in the expected direction (Table 6). For example, a high level of uncertainty resulted in a higher riskrating, as did limited preview distance and presence of an intersection.

The effects of four significant scene characteristics were in the unexpected direction (Table 6). Specifically, high level of complexity, and presence of tunnel/bridge, animals, and pedestrians/bicyclists resulted in a lower risk-rating. Three of these four unexpected effects can be explained on a post-hoc basis. Tunnels and bridges make lateral intrusions of other vehicles impossible, while animals, pedestrians, and bicyclists might be viewed as less dangerous than cars and trucks. Again, the veridicality of the risk assessment of these characteristics cannot be ascertained.

The risk ratings were unaffected by four scene characteristics: ambient illumination, density of traffic, stopped vehicles in the lane of travel, and overtaking.

\section{Differences among countries}

U.S. subjects tended to give the lowest risk-ratings of traffic scenes, while Spanish subjects tended to give the highest risk-ratings. This pattern was present for both the grand means of all 100 risk ratings (Table 4) and for the rank orders of the individual scenes (Table 5).

Table 5. Rank order distributions of the means of all 100 scenes by country (rank order 1 indicates that the scene was given the lowest rating of the four countries, while rank order 4 indicates the highest rating of the four countries)

\begin{tabular}{c|c|c|c|c}
\hline \multirow{2}{*}{$\begin{array}{c}\text { Rank order } \\
\text { by country }\end{array}$} & U.S.A. & Spain & West Germany & Brazil \\
\cline { 2 - 5 } & 45 & $7.5+$ & 20.5 & 27 \\
1 & 40.5 & 12.5 & 27.5 & 19.5 \\
2 & 9.5 & 25.5 & 43 & 22 \\
3 & 5 & 54.5 & 9 & 31.5 \\
\hline 4 & 100 & 100 & 100 & 100 \\
\hline
\end{tabular}

tA decimal indicates that for a particular scene there was a tie for a rank order. 
Table 6 . The results of the analyses of the beta weights for the 23 scene characteristics (a bold entry in the second column indicates that the beta weight was significantly different from zero; a letter entry in the third through fifth columns indicates that the beta weight for the particular level of the variable was different from zero; in both cases $p<.0001144$ )

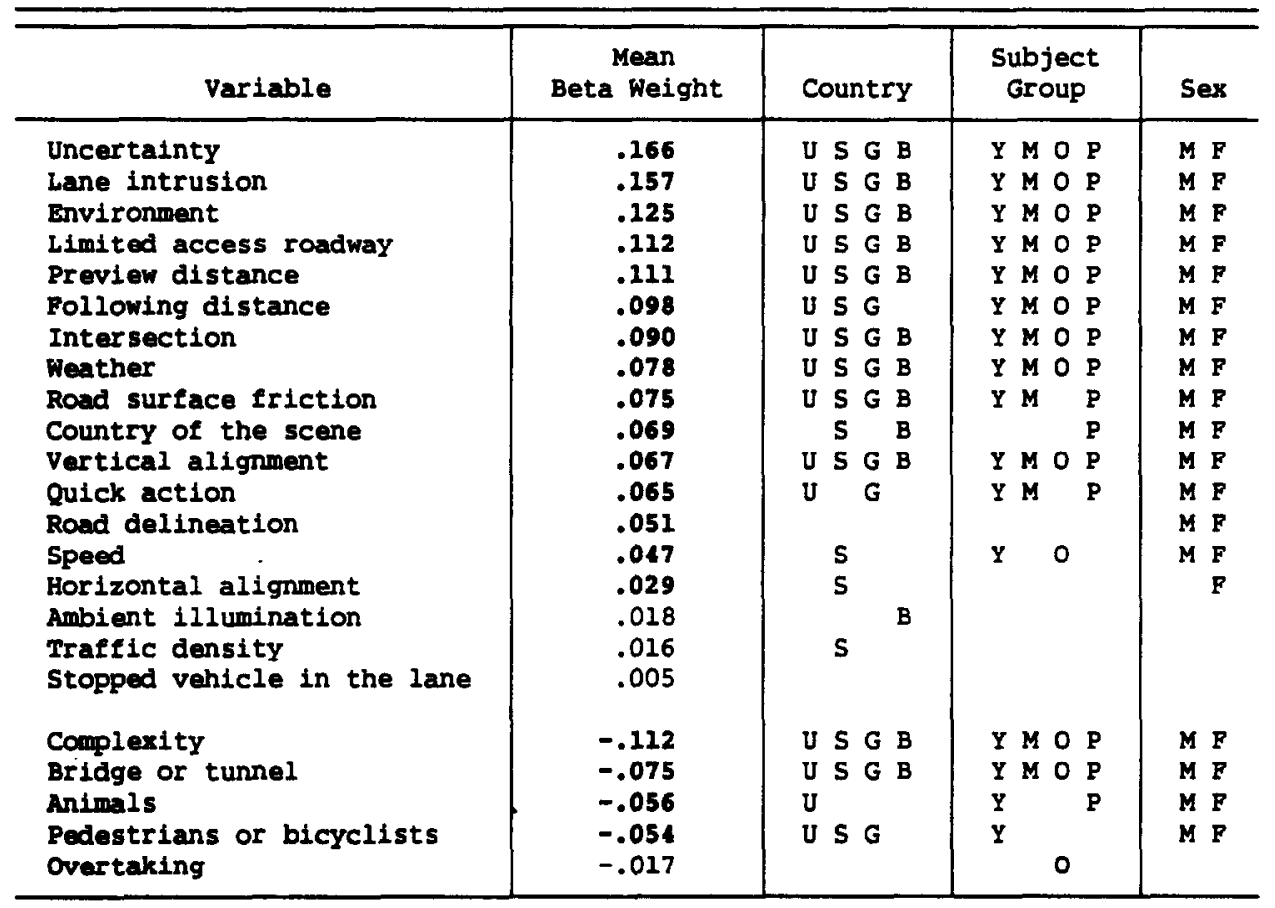

Note. Country: $U=$ U.S.A., $S=$ Spain, $G=$ West Germany, $B=$ Brazil.

Subject group: $Y=$ younger, $M=$ middle-aged, $O=$ older,$P=$ middle-aged professional.

Sex: $M=$ males, $F=$ females.

Table 7. Statistically significant differences in beta weights among countries and among subject groups $(p<.0001144)$; the entries are the corresponding beta weights

\begin{tabular}{|c|c|c|c|c|}
\hline \multirow{2}{*}{ Variable } & \multicolumn{4}{|c|}{ Country } \\
\hline & U.S.A. & Spain & West Germany & Brazil \\
\hline $\begin{array}{l}\text { Lane intrusion } \\
\text { Environment } \\
\text { Following distance } \\
\text { Country of the scene } \\
\text { Quick action } \\
\text { Speed } \\
\text { Ambient illumination } \\
\text { Complexity } \\
\text { Animals } \\
\text { Pedestrians or bicyclists }\end{array}$ & $\begin{array}{r}.181 \\
.112 \\
.129 \\
.015 \\
.126 \\
.010 \\
-.020 \\
-.097 \\
-.135 \\
-.102\end{array}$ & $\begin{array}{r}.107 \\
.099 \\
.111 \\
.101 \\
.049 \\
.127 \\
.021 \\
-.167 \\
-.036 \\
-.065\end{array}$ & $\begin{array}{r}.139 \\
.106 \\
.112 \\
-.058 \\
.080 \\
.041 \\
.007 \\
-.120 \\
-.041 \\
-.053\end{array}$ & $\begin{array}{r}.201 \\
.183 \\
.040 \\
.216 \\
.006 \\
.032 \\
.064 \\
-.064 \\
-.014 \\
.002\end{array}$ \\
\hline & \multicolumn{4}{|c|}{ Subject Group } \\
\hline Variable & Younger & Middle-Aged & older & $\begin{array}{l}\text { Middle-aged } \\
\text { professional }\end{array}$ \\
\hline $\begin{array}{l}\text { Road surface friction } \\
\text { Speed }\end{array}$ & $\begin{array}{l}.111 \\
.054\end{array}$ & $\begin{array}{l}.080 \\
.031\end{array}$ & $\begin{array}{l}.037 \\
.100\end{array}$ & $\begin{array}{l}.072 \\
.005\end{array}$ \\
\hline
\end{tabular}


Two sets of tests evaluated the differences among countries in the sensitivity to the 23 scene characteristics. The first set evaluated for each country the differences from zero of the beta weights for the scene characteristics. The results of these tests (Table 6) showed that for nine scene characteristics the beta weights were different from zero for at least one but fewer than four countries.

The differences among the countries were tested more directly in the second set of analyses. Here analyses of variance were used to evaluate the main effects of country on the beta weights for the scene characteristics. The results indicate that 10 scene characteristics contributed differentially to risk ratings in the tested countries (see Table 7): lane intrusion, environment, following distance, country of the scene, potential for quick action, speed, ambient illumination, complexity, animals, and pedestrians/ bicyclists. Potential for quick action, presence of animals, and presence of pedestrians/ bicyclists had the greatest effect (the latter two in the unexpected direction) on U.S. drivers. Similarly, complexity (also in the unexpected direction) and high speed had the greatest effect on Spanish drivers. Finally, lane intrusion, country of the scene (Spanish scenes being judged more risky), low level of ambient illumination, and urban environment had the greatest effect on Brazilian drivers, but insufficient following distance had the least effect on Brazilian drivers.

The U.S., Spanish, West German, and Brazilian subjects, in addition to being drawn from different countries, differed in other aspects, such as the size of the city of domicile and the means of recruitment for the study. Consequently, it cannot be excluded that the presumed effects of country are due to differential sampling.

\section{Differences among subject groups based on age and experience}

Younger drivers in all countries tended to report lower risk than did middle-aged or older drivers (Table 4)-in agreement with previous studies (e.g. Cairney 1982; Finn and Bragg 1986; Matthews and Moran 1986). Consequently, this study provides some support for the hypothesis that lower perceived risk might be one factor in young drivers' overrepresentation in road accidents (Williams 1985).

As with the differences among countries, two sets of tests evaluated the differences among subject groups in the sensitivity to the 23 scene characteristics. The first set evaluated for each subject group the differences from zero of the beta weights for the scene characteristics. The results of these tests (Table 6) showed that for seven scene characteristics the beta weights were different from zero for at least one but less than four subject groups.

The differences among the subject groups were tested more directly in the second set of analyses. Here analyses of variance were used to evaluate the main effects of subject group on the beta weights for the scene characteristics. The results indicate (Table 7) that two scene characteristics contributed differentially to risk ratings in the four tested subject groups: road surface friction and speed. Older subjects were more responsive to high speed than were middle-aged and younger subjects. On the other hand, older subjects were less responsive to low road-surface friction than were middleaged and especially younger subjects.

None of the characteristics of the scenes contributed differentially to the risk ratings of professional and nonprofessional drivers of the same age. This finding implies that, at least for the middle-aged drivers, added experience does not lead to differential contribution of various factors on perceived risk.

\section{Differences between sexes}

None of the characteristics of the scenes contributed differentially to the risk ratings of males and females, whether the analyses focused on the differences from zero of the beta weights (Table 6) or on the differences among the beta weights (Table 7).

\section{Potential practical implications}

This study provides some evidence that certain situational characteristics might differentially effect the perception of risk by drivers from different countries and of 
different ages. Furthermore, some of the evaluated situational characteristics did not affect the perceived risk of drivers from any country or age group. Consequently, these findings provide some indication of the desirable country- and age-specific focus of driver education, driver licensing, and public information campaigns.

Acknowledgements-Appreciation is extended to Michael J. Flannagan for performing most of the statistical analyses and to A. Regula Herzog, Maribel Maspons, Paul L. Olson, and the professionals of the Instituto de Psicologia y Medicina de Trafico in Valencia for their advice and assistance. This research was supported, in part, by the U.S.-Spain Joint Committee for Scientific and Technological Cooperation in Madrid, Spain.

\section{REFERENCES}

Cairney, P. T. An exploratory study of risk estimates of driving situations. Aust. Road Res. Board Proc., 11(5):233-240; 1982

Finn, P.; Bragg, B. W. E. Perception of the risk of an accident by young and older drivers. Accid. Anal. Prev., 18:289-298; 1986.

Matthews, M. L.; Moran, A. R. Age differences in male drivers' perception of accident risk: The role of perceived driving ability. Accid. Anal. Prev, 18:299-313; 1986.

Morrison, D. F. Multivariate statistical methods, 2nd ed. New York: McGraw-Hill; 1976.

Sivak, M.; Soler, J.; Tränkle, U. Cross-cultural differences in driver risk-taking. Accid. Anal. Prev. 21:363$369 ; 1989$ a.

Sivak, M.; Soler, J.; Tränkle, U. Cross-cultural differences in driver self-assessment. Accid. Anal. Prev. $21: 371-375 ; 1989 \mathrm{~b}$

von Benda, H.; Hoyos, C. G. Estimating hazards in traffic situations. Accid. Anal. Prev. 15:1-9; 1983.

Williams, A. F. Nighttime driving and fatal crash involvement of teenagers. Accid. Anal. Prev. 17:1-5; 1985. 